\title{
Implementation of Goal-Oriented Budgeting in the Defence Sector
}

\author{
Petr MUSIL ${ }^{1}$
}

This article describes the starting points for implementing goal-oriented budgeting (management by objectives) into the Ministry of Defence of the Czech Republic. It also focuses on the principles and factors that affect implementation.

Keywords: planning, budgeting, goal-oriented budgeting (MBO), goal.

\section{Introduction}

On the $1^{\text {st }}$ of January 2009, Decree No. 415/2008 Coll. establishing the scope and structure of documentation for the development of the medium-term national budget outlook became effective. On the basis of this Decree, the budgeting was initiated in compliance with the methodology for goal-oriented budgeting (MBO) not only at the Ministry of Defence of the Czech Republic (MoD, CR), but also in other budget chapters in the Czech Republic. The implementation of the new system which has an impact on the finance management began in 2009. Under the new rules, the budget was compiled for 2010 for the first time. [1]

\section{Goal-oriented budgeting}

The concept of goal-oriented budgeting is used in two basic meanings. The first concept is broader and represents the resource management system. The second concept is narrower and it is the budget method. Thus, the nature of goal-oriented budgeting is rationalizing resource allocation.

Goal-oriented budgeting is such a resource management system that enables the transformation of identified public needs into the form of a particular ministry goals and the cover of these goals with regard to their priorities and limited resources. [2]

Goal-oriented budgeting is a new allocation system that is to make it possible to answer the question: "What is to be achieved, how and with what amount of money?" To find the answer to this question means the following: [3]

- To realize the mission of a given institution and the benefits of its activities for the public and the state (general goal setting including the time horizon),

- To analyse activities, to determine their purpose and how they contribute to the set goals, and thus to create their homogeneous units (the definition of expenditure block structure and a more detailed division),

- To assign expenditure to these activities (expenditure assignment to expenditure blocks and a more detailed division).

1 Lieutenant-Colonel, MSc, University of Defence Brno. He heads Financial Management Section, Department of Economy, Faculty of Economics and Management. He deals with issues of planning, programming and budgeting financial resources in public sector and sector Ministry of Defence. petr.musil2@unob.cz 
To implement a new approach to be successful, it is necessary:

- To know the source and target state of goal-oriented budgeting (Table 1.),

- To adapt the program structure of the Ministry of Defence, the thinking of responsible workers as well as the software support of the entire system.

The successful implementation is further subject to the adequate regulation of the external and internal legislative documents. Goal-oriented budgeting should allow the workers of the Ministry of Defence to fulfil the obligations resulting from Act No. 320/2001 Coll., on financial control, i.e. the efficient, economical and sensible use of financial resources. Currently, we are able to identify inputs (we have information on expenditure), but we are not able to identify our outputs in relation to the fulfilment of economic evaluation of financial resources. This new system should enable these deficiencies to be removed.

\begin{tabular}{|c|c|c|}
\hline $\begin{array}{l}\text { Field of state budget } \\
\text { creation in the Czech } \\
\text { Republic }\end{array}$ & Initial state & Target state \\
\hline $\begin{array}{l}\text { Methodological approach to } \\
\text { budgeting }\end{array}$ & Supply & Demand \\
\hline $\begin{array}{l}\text { Final recipient of financial } \\
\text { flows }\end{array}$ & Institution & Targeted activities (goals) \\
\hline Budget method used & $\begin{array}{l}\text { Index or incremental lean- } \\
\text { ing against a historical basis }\end{array}$ & Goal-oriented budgeting \\
\hline $\begin{array}{l}\text { Method of budgetary treat- } \\
\text { ment of incomes }\end{array}$ & Gross-budgeting & Net-budgeting \\
\hline $\begin{array}{l}\text { Method of budgetary treat- } \\
\text { ment of expenditure }\end{array}$ & $\begin{array}{l}\text { “Consumer” system of } \\
\text { expenditure treatment }\end{array}$ & $\begin{array}{c}\text { Production system of ex- } \\
\text { penditure treatment }\end{array}$ \\
\hline $\begin{array}{l}\text { Method for monitoring } \\
\text { public expenditure }\end{array}$ & $\begin{array}{l}\text { Formal control (accounting } \\
\text { and documentation) }\end{array}$ & $\begin{array}{c}\text { Factual and content control } \\
\text { (control of purpose, effect } \\
\text { and impact of realized } \\
\text { expenditure) }\end{array}$ \\
\hline Public inspection & $\begin{array}{l}\text { Performed by external audit } \\
\text { as audit of compliance with } \\
\text { the accounting and legal } \\
\text { documentation }\end{array}$ & $\begin{array}{l}\text { Factual control of public } \\
\text { policies through the moni- } \\
\text { toring of expenditure goals } \\
\text { of the state budget } \\
\text { individual chapters }\end{array}$ \\
\hline Accounting & $\begin{array}{l}\text { Single-entry bookkeeping, } \\
\text { accounting for expenditure }\end{array}$ & $\begin{array}{c}\text { Double-entry bookkeeping, } \\
\text { managerial accounting, cost } \\
\text { accounting }\end{array}$ \\
\hline Time horizon & $\begin{array}{l}\text { Short-term or medium- } \\
\text { term with insufficiently long } \\
\text { outlook }\end{array}$ & $\begin{array}{l}\text { Medium-term (rolling, } \\
\text { moving) budget }\end{array}$ \\
\hline
\end{tabular}

Table 1. Initial and target state in the creation of the state budget of the Czech Republic [4: 18] 
This is a completely new system for preparing and implementing the budget through the Management by Objectives (MBO) method which will be introduced in phases in the course of several years. In this context, a set of objectives has been created at the Ministry of Defence, which is expressed in Figure 1. The budget structure is represented by homogenous units of activities which constitute expenditure blocks (EB) - the first level objectives. These are further divided into expenditure areas (EA) - the objectives of the second level and the lower level division (the similar method of specification applies to objectives as well), while a higher level is a complete sum of the directly subordinate levels. The determination of EB and $\mathrm{EH}$ is mandatory, other lower-level divisions are voluntary.

\section{Implementation principles}

The implementation principles of goal-oriented budgeting at the Ministry of Defence Article 6.4 - regulate the area of "creating objectives and working with objectives in the budget preparation" which define the objectives as projects / sub-projects. The "target manager" is responsible for the content and development of various kinds of objectives. He/she is an "official of the Ministry of Defence selected by the top management and is responsible for the development and management of objective (project) implementation and provided with adequate authority"[5]. Within the process of developing objectives in each level, target managers should use the "SMART" method in compliance with the principles of goaloriented budgeting. "The requirement for setting measurable parameters to evaluate the accomplishment of goals must always be taken into account when the content of the goal is defined"[6]. The goals are determined according to particular levels from the highest one, usually called the zero level (goal " 0 " order) up to the n-th level which is necessary for the management of the organization. The goals of the lower level are not set forth unless the higher level goal divide at least into two sub-goals. The goals of the zero level are based on $\S 16$ of Act No. 2/1969 Coll. of the Czech National Council on the establishment of ministries and other central bodies of state administration of the Czech Socialist Republic (the so-called Jurisdictional Act) and are the basic mission of the organization. These goals are elaborated and clarified in lower levels as strategic, tactical and operational ones. Within the Ministry of Defence, the first level of goals is determined by long-term strategic goals of the Ministry of Defence which result from the Long-Term Development Perspective of the Ministry of Defence and are regulated by the Directive. The second level goals are medium-term goals and are laid down by the Directive. The third level goals are determined by managerial personnel directly subordinated to the Minister of Defence in relation to the higher level goals and are approved by the Planning Conference. The length of experience will show how the given method will be applied in creating particular goals. Subsequently, these goals are divided into the lower levels of goals which we call measures and tasks.

The goals are elaborated in a hierarchical structure - the goal tree:

- The first level goal - the expenditure block (the first level goals are shown in Table 2.)

- The second level goal - the expenditure area,

- The third level goal,

- Task,

- Measures,

- Activity. 


\begin{tabular}{|c|c|}
\hline $\begin{array}{c}\text { Number of the } \\
\text { first level goal }\end{array}$ & Name of the goal \\
\hline 1. & Provision of the Czech Republic defence by the armed forces. \\
\hline 2. & Creation and development of the national defence system. \\
\hline 3. & Provision of the Public Administration operation at the Ministry \\
of Defence.
\end{tabular}

Table 2. The MoD system of goals for the planning cycle for 2013-2017 (the first level goals) [7]

\section{Factors affecting the implementation}

Currently, the planning and budgeting area occurs in the so-called transition period. There is a continuous reduction of expenditure (allocated financial resources) at the Ministry of Defence. This entails undesirable consequences. Then there are problems with the implementation of goal-oriented budgeting. The Ministry of Defence elaborates analyses in the area of planning and budgeting which highlight the problems concerning the implementation of goal-oriented budgeting. These are mainly:

- The used concepts have not been clarified within the implementation,

- Provision of internal standards has been implemented only partially,

- The workers involved have not been trained adequately,

- Inability / unwillingness of the workers concerned to learn new things,

- The issue of management by objectives is considered to be an "economic" discipline, the personnel of planning components take part very unwillingly,

- Lack of cohesion of the factual and financial planning,

- The planning is not able to respond to changes in the source frame,

- Etc.

The issue of the new budgeting system is characterized by the following advantages and disadvantages.

The new budgeting system - advantages:

- The tool coordinating the efforts of employees to achieve organizational goals,

- Allows objective evaluation of the effectiveness,

- Supports motivation to improve the individual performance,

- Allows identifying problem areas in relation to achieving goals.

- The new system of budgeting - disadvantages:

- Time-consuming,

- A lot of "paperwork”,

- Problems in goal-setting, 
- Risk of inflexibility,

- Emphasis on short-term goals,

- Inadequate or irrelevant information provided by the authors of goals.

\section{Conclusion}

Based on the abovementioned fact, it is clear that the issues of the new system-of-budgeting implementation are very difficult. The changes that have occurred in the process of budgeting and planning should lead to a more rational management of budgetary resources within the Ministry of Defence. When assessing the current state of the examined questions, I must state that the options offered for the accomplishment of goals and the mission of military units have not been utilized efficiently, so that they could lead to a more rational management of resources (factual, financial, human).

At the present, when the Czech economy is facing the economic crisis, the basic task of the management will be to support effective, efficient and economical use of resources. The resource management should include the entire cycle of planning, budgeting (programming) and resource utilization for individual goals from accounting up to their analysis.

\section{References}

[1] Manuály. Ministerstvo financí ČR. c2005 http://www.mfcr.cz/cps/rde/xchg/mfcr/xsl/ vyhlasky_44707.html?year=2009. (downloaded: 0806 2012)

[2] OCHRANA, F.: Cílově orientované rozpočtování - stav a perspektivy jeho uplatnění v rezortu Ministerstva obrany. Vojenské rozhledy, 3 (2010). http://www.army.cz/assets/ multimedia-a-knihovna/casopisy/vojenske-rozhledy/vr-3.pdf (downloaded: 0806 2012)

[3] KRTIL, J.: Cílově orientované rozpočtování. Praha, 2010. Prezentace

[4] OCHRANA, F.: Veřejné rozpočty jako nástroj ř́zení. Praha. Projekt CZ.2.17/3.1.00/31197, s. 18.

[5] Čl. č. 5.20, ZÁSADY implementace cílově orientovaného rozpočtování (COR) u Ministerstva obrany. Praha: Ministerstvo obrany, 2010. s. 40. Čj. 132-1/2010-8201.

[6] Čl. č. 6.3, ZÁSADY implementace cílově orientovaného rozpočtování (COR) u Ministerstva obrany. Praha: Ministerstvo obrany, 2010. s. 40. Čj. 132-1/2010-8201.

[7] Soustava cílů rezortu MO pro plánovací cyklus 2013-2017. Praha: Ministerstvo Obrany, 2013. Čj. 97-28/2013-3691. 